This item was submitted to Loughborough's Research Repository by the author.

Items in Figshare are protected by copyright, with all rights reserved, unless otherwise indicated.

\title{
Scholarly output: print and digital - in teaching and research
}

PLEASE CITE THE PUBLISHED VERSION

http://dx.doi.org/10.1108/00220411011038467

PUBLISHER

(c) Emerald Group Publishing Limited

VERSION

AM (Accepted Manuscript)

LICENCE

CC BY-NC-ND 4.0

REPOSITORY RECORD

Maynard, Sally, and Ann O'Brien. 2019. "Scholarly Output: Print and Digital - in Teaching and Research". figshare. https://hdl.handle.net/2134/14634. 
This item was submitted to Loughborough's Institutional Repository (https://dspace.lboro.ac.uk/) by the author and is made available under the following Creative Commons Licence conditions.

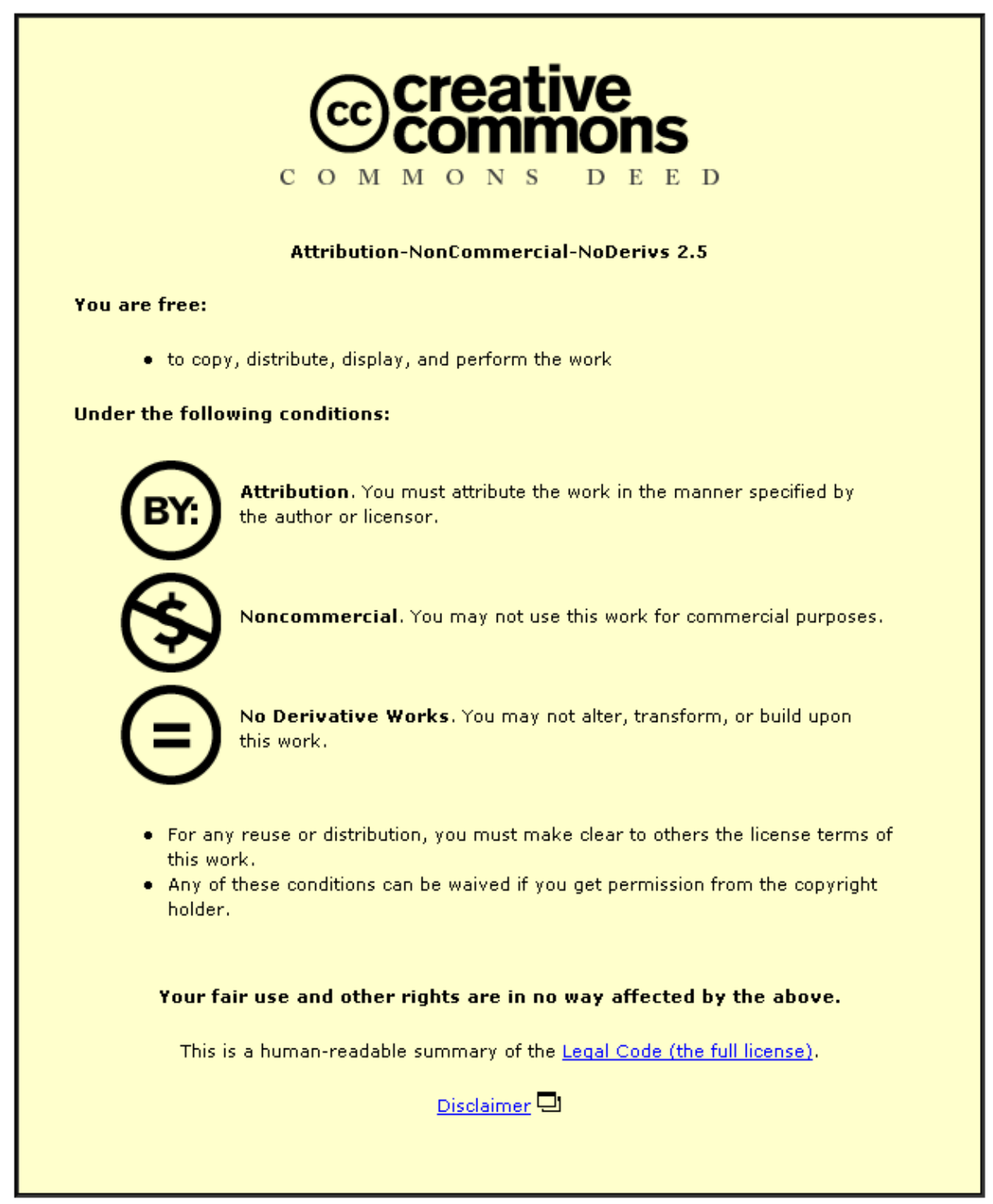

For the full text of this licence, please go to: http://creativecommons.org/licenses/by-nc-nd/2.5/ 


\title{
Scholarly output: print and digital - in teaching and research
}

Sally Maynard and Ann O'Brien, Department of Information Science, Loughborough University

\begin{abstract}
Purpose

This paper reports the outcomes of a JISC sponsored study (2007) to determine the current state and trends in different forms of scholarly output used in teaching and research; and the nature and extent of problems associated with their use.

\section{Design/methodologylapproach}

A total of $60 \mathrm{UK}$ HE institutions was chosen at random and a selection of departments within these were contacted. An online questionnaire was distributed to the selected departments; this resulted in responses from 304 academics across a broad range of subjects and institution types.

\section{Findings}

The study showed that printed output was still the preferred option in both teaching and research, although electronic journals now have a well established presence. Web-based material is increasingly provided in teaching and used in research but this includes primarily traditional tools such as reading lists and links to scholarly resources. Some content creation was evident.
\end{abstract}

Use of web 2.0 was not extensive, although respondents were making use of Institutional Learning Environments. Academics were aware of IPR issues but not always clear about their responsibilities in this area.

\section{Research limitations/implications}

This study revealed an essentially conservative approach to the developments in digital information. This may have been due to the sample size which was relatively small, and the age profile which clustered around the 45-65 years range. In the case of research the influence of the RAE was clear.

\section{Originality/value}

No equivalent study has been reported on the transition between traditional and new forms of scholarly output used in teaching and research. In this fast developing area this research provides a benchmark for future studies.

Category: research paper.

Keywords:

Scholarly publication, teaching, research, Web 2.0 , Intellectual property rights. 


\section{Introduction}

Given the proliferation of digital/electronic resources, it is assumed that researchers and educators are making use of the variety of different forms and formats that are readily available. While this is well known and accepted, there is still little hard knowledge on how, when and in what contexts different forms of scholarly output are used. The Joint Information Systems Committee (JISC) commissioned LISU at Loughborough University to carry out a study to discover needs for different forms of scholarly output, the nature and extent of their use and any problems met by content creators or users. This article presents a selection of results from the study ${ }^{1}$.

Since the first scholarly journals entered publication (almost 350 years ago according to Swan, 2006), the printed word has been the primary, formal, means by which scholars have communicated the results of their work and have "established their right to the intellectual property reported in their articles" (Swan, 2006). Up to recent times, therefore, scholarly output has mainly taken the form of some sort of printed publication, and this has been universally adopted by scholars in all subjects. However, the advent of microchip technology has led to the development of an ever-expanding variety of new electronic technologies, and these are increasingly being used to present scholarly output. There is little appreciation or evidence of how, when and in what contexts, different forms of scholarly output are used.

There might be an assumption that new technologies and the recent developments in social software have become commonplace in academic circles. This study attempted to look in depth at academic practice in teaching and research in order to offer a snapshot of practice in 2007.

\section{Background}

The more traditional kinds of scholarly output are well established, with accepted widespread use of printed books (including textbooks, research monographs, conference proceedings etc.), printed journal articles and, to a lesser extent, other printed material such as professional journals, newspapers and magazines. In the past decade, electronic versions of journals and new titles only available electronically have also been more widely used and recognised as an important part of scholarly communication. However, the extent to which the very new forms of electronic communication and digital media are being used by the HE community is less clear.

Anecdotal evidence and some focused studies suggest that academics are currently making use of many types of output (both scholarly and 'non scholarly'); indeed, this was a conclusion of the research carried out by Armstrong and Norton (2006). Information and communication technologies (ICTs) can enable new forms of teaching and learning to take place (see, for example, Kirkwood and Price, 2007). As a result, the expectations of information users in colleges and universities are changing; there is an increasing reliance on electronic resources and on the Internet in general (see, for example, Marcum and George, 2003 and Wakeham and Garfield, 2005).

\footnotetext{
${ }^{1}$ Full report available at http://www.jisc.ac.uk/media/documents/aboutus/workinggroups/differentscholarlyoutput.pdf
} 
Furthermore, it is likely that use of multi-format resources is becoming more prevalent across many subject areas (see, for example, Wakeham and Garfield, 2005) However, the choice of materials used is relatively discipline specific (Armstrong and Norton, 2006). The fields of teaching and research may also require and make use of differing resources.

\section{Blended learning}

Also known as "hybrid learning, flexible learning, and web-enhanced instruction" (Codone, 2004), the concept of blended learning has become widely accepted over the past five years (Allen, 2007). It is typically indicated "by a combination of learning strategies and resources that creates a multifunctional instructional experience" (Codone, 2004), which means that the potential of new technology can both be exploited and interpreted by academic staff. In this way, electronic technologies can supplement the more traditional teaching methods.

Sharpe et al (2006) identify three ways in which the term 'blended learning' is currently being used. The most common use relates to the provision of supplementary resources for courses being conducted along mainly "traditional lines" and delivered via institutionally supported virtual learning environments (VLEs). The second most common type of blended learning is concerned with examples of the "... use of technology to facilitate interaction and communication", which replace other methods of teaching and learning (p. 2). Lastly, there is evidence that students themselves demonstrate original approaches to learning, making use of the new technology in a way which seems to bypass many university facilities. This is seen in the use of such tools as mobile phones, MSN, weblogs and wikis to enable them to work collaboratively and supportively in an independent manner.

\section{Web 2.0 and social software}

A key advance has been the development of Web 2.0 'social software'. The term is defined simply as "software that supports group interaction" (Shirky, 2003, quoted in Owen et al., 2006). Such software can bring some of the elements of sociability together with those of computing, meaning that it supports conversational interaction between individuals and groups and allows social feedback in which a group can rate the contributions of others. Social software can also offer support for social networks which create and manage a digital expression of personal relationships and help in the building of new relationships. Some of the key attributes of social software in relation to education include the fact that it delivers communication between groups, enables communication between many people, provides gathering and sharing resources, delivers collaborative collecting and indexing of information, allows syndication and assists personalisation of priorities, has new tools for knowledge aggregation and creation of new knowledge and delivers to many platforms as is appropriate to the creator, recipient and context (Owen et al., 2006).

In attempting to address the Web 2.0 issues facing HE, Anderson (2007) notes the current lack of "reliable, original pedagogic research and evaluation evidence" (p. 32) relating to the advantages and disadvantages of integrating social software in mainstream education. However, some of the examples of preliminary activity in learning and teaching and scholarly research cited by Anderson include the use of wikis at the University of Arizona to help distance learning students on an information studies course (Glogoff, 2006) and at Oxford University to support teachers (Phoebe Pedagogic Planner, 2007).

In aiming to explore the various forms of direct publishing and content aggregation tools currently available to educators and the range of educational activities to which they are being applied, Placing et al (2005) searched for examples of how blogs are being used. A 
blog can offer "a useful space for course planning or the sharing of resources and communication throughout a research project" (p.159) (Placing et al 2005). It is therefore clear that blogs can be valuable in education, both as a means by which to communicate the results of scholarly work, and as an aid to teaching.

Social bookmarking is a method by which users store lists of internet resources which they find useful; existing examples are too numerous to mention, but a currently popular example is del.icio.us (http://del.icio.us/). Other innovative examples are discussed by Alexander (2006). The pedagogical role which can be played by social bookmarking in HE lies in its ability to facilitate collaborative information discovery (see Alexander, 2006 for further details).

Librarians represent a specific group which has explored the potential of Web 2.0 in teaching and learning. One of the most pressing issues for libraries is the increased perception of students that the library is no longer a necessity for study, as so much material is available on the web. As a result, librarians are active in incorporating features from Web 2.0 into library services in an attempt to offer students an environment that is in tune with their typical personal technologies. The LASSIE project (2008) explored how the use of social software might assist distance learners, particularly in their use of libraries. It brought together good evidence of practice in a comprehensive literature review and initiated a set of case studies. JISC has also commissioned research and produced position papers on the topic (JISC, 2007a) as well as reporting results from various e-learning projects (JISC, 2007b).

Educationalists and educational technologists, especially those involved in delivering distance or blended learning are also important players in novel forms of communication in teaching and learning but there is as yet little evidence as to the degree to which 'ordinary academics' have taken the plunge. A recent report from Ithaka (Housewright \& Schonfeld 2008), based on data collected in 2006 from 4,100 academics and 350 librarians in the USA, investigated attitudes to the transition from print to electronic media in scholarship and also preferences in research practices, including disciplinary differences and changes over time. The results show that the various disciplines demonstrate different needs and attitudes, for example, humanities scholars do not move as quickly into digital information as scientists; and although historical patterns of scholarship and scholarly communication are shifting, there is a reluctance to lose what are regarded as important scholarly values.

\section{Research}

The new technologies which are likely to be of particular interest to HE researchers are those which are useful in the research environment, particularly in terms of their ease of use, support for collaboration and non-linear nature (Anderson, 2007). Four specific technology areas have been adopted and developed by the research community. These are: social tagging; folksonomies; blogging and bookmarking (discussed above); and scientific data mash-ups. However, the suitability of the folksonomy within formal knowledge management environments is the subject of much debate; this is perhaps a form which requires further development.

Blogging has been discussed above in terms of learning and teaching; there is, however, evidence to suggest that it enables researchers in all disciplines to engage in peer debate, share early results or seek help with experimental issues (Skipper, 2006). However, it 
seems that few instances of such blogs exist (Placing et al, 2005), and this issue requires further investigation.

Therefore, it can be seen that, while the use of social software (or Web 2.0) is becoming more widely recognised and understood within the HE community, evidence of its use is still scarce. The survey described below attempts to fill this gap in knowledge.

\section{Research design}

The survey instrument for the research was an online questionnaire. A two-stage cluster sampling strategy was employed. Firstly, a random sample of 20 institutions was selected from the HESA list of HE institutions. Within each institution, up to five departments were identified (once again at random), from different faculties/schools. A balance between institution types and subject disciplines was ensured.

The head of each selected department was contacted in order to inform them that they would soon be contacted again and asked to distribute details of the questionnaire to all members of academic staff within their department. The message was designed so that it could be simply forwarded to the relevant contacts. It was hoped that this would provide a representative mix of academic staff involved primarily in both teaching and in research. An incentive prize was offered to respondents in order to maximise response rates.

Towards the end of the survey period, departments were contacted and asked to circulate the details of the study again, to further encourage response. In addition, since the response rate was well below the level required, it was decided to extend the invitation to participate to a further 20 institutions. The institutions were again selected at random.

Despite these actions, however, the response rate remained below that which was required. Consequently, a final third random sample of 20 institutions was identified and a selection of departments was singled out; the heads of these were contacted in the same way as before.

This resulted in a final total of 304 useable replies, reaching the number specified by JISC and a limit constrained by the timescale of the project. Of the 60 institutions contacted, 14 did not reply at all. Disappointingly, there were 20 institutions from which fewer than five responses were received. Table 1 shows the responses by type of institution.

\section{Table 1: Responses by institution}

\begin{tabular}{lcc} 
Institution & $\begin{array}{c}\text { No. of } \\
\text { responses }\end{array}$ & \multicolumn{1}{c}{$\%$} \\
\hline Pre-1992 Universities & 149 & 49.0 \\
Post-1992 Universities & 122 & 40.1 \\
HE Colleges & 33 & 10.9 \\
TOTAL & $\mathbf{3 0 4}$ & $\mathbf{1 0 0 . 0}$
\end{tabular}

Table 2 shows the broad subject disciplines in which respondents reported they worked. The list was compiled from that utilised by the Higher Education Statistics Agency (HESA) in its regular publications. As can be seen from the Table, the highest proportion of respondents were involved in 'Science and Engineering'; 19 respondents could not identify their subject from the categories provided and selected 'Other'. 


\section{Table 2: $\quad$ Responses by subject discipline}

\begin{tabular}{lcr} 
Subject discipline & $\begin{array}{c}\text { No. of } \\
\text { responses }\end{array}$ & $\%$ \\
\hline Arts and Humanities & 80 & 26.4 \\
Medical and related & 40 & 13.2 \\
Social Sciences (including & & \\
$\quad$ Business) & 73 & 24.0 \\
Science and Engineering & 92 & 30.2 \\
Other & 19 & 6.3 \\
TOTAL & 304 & $\mathbf{1 0 0 . 0}$
\end{tabular}

Compared to the distribution of academic professionals overall in 2006-07 (HESA, 2007), Medical and related subjects are significantly under-represented in the eventual sample, and Arts and Humanities and Social Sciences are over-represented.

Table 3 details respondents by age group; it shows that the largest proportion of participants were aged 46-55 years (26.3\%). There were few responses from those aged 26-35 years only $1.6 \%$ compared to the $25 \%$ of all academic professionals quoted by HESA (2007); it is not immediately apparent why this might be the case. Those aged over 55 years were significantly over-represented in the sample compared to the overall age distribution of academic professionals in $2006-07$ (40\% of the sample compared to $18 \%$ of the population (HESA, 2007).

\section{Table 3: Responses by age group}

\begin{tabular}{lcr} 
Age group & $\begin{array}{c}\text { No. of } \\
\text { responses }\end{array}$ & \multicolumn{1}{c}{$\%$} \\
\hline 18-25 years & 35 & 11.5 \\
26-35 years & 5 & 1.6 \\
36-45 years & 58 & 19.1 \\
46-55 years & 80 & 26.3 \\
56-65 years & 75 & 24.7 \\
65+ years & 44 & 14.5 \\
No response & 7 & 2.3 \\
Total & $\mathbf{3 0 4}$ & $\mathbf{1 0 0 . 0}$ \\
\hline
\end{tabular}

There was a higher proportion of male participants (57\%) over female (40\%), with $3 \%$ of respondents not providing details. The gender breakdown is in line with the distribution of academic professionals overall in 2006-07 (HESA, 2007) (58\% male; 42\% female).

Respondents were asked to provide approximate percentages of time spent on teaching, research and administration. For the purposes of reporting the results, the responses have been sorted into bands of $10 \%$ and are summarised in Table 4 . There was a relatively wide range of answers for time spent on teaching, and the median value was $40 \%$. The mode (the most frequent value) was also $40 \%$. 
Table 4: Approximate percentage of time spent on teaching, research and administration/other

\begin{tabular}{lrcc}
$\begin{array}{l}\text { Approximate } \\
\text { time (respondents) }\end{array}$ & $\begin{array}{c}\text { Teaching } \\
(\%)\end{array}$ & $\begin{array}{c}\text { Research } \\
(\%)\end{array}$ & $\begin{array}{c}\text { Admin/other } \\
(\%)\end{array}$ \\
\hline No response & 0.7 & 0.7 & 0.7 \\
$0 \%$ & 8.6 & 6.9 & 3.9 \\
$1 \%-10 \%$ & 10.2 & 21.1 & 13.5 \\
$11 \%-20 \%$ & 7.9 & 16.8 & 25.0 \\
$21 \%-30 \%$ & 14.8 & 16.1 & 18.1 \\
$31 \%-40 \%$ & 18.8 & 14.8 & 16.4 \\
$41 \%-50 \%$ & 15.8 & 9.5 & 9.9 \\
$51 \%-60 \%$ & 10.2 & 2.6 & 4.3 \\
$61 \%-70 \%$ & 5.9 & 2.3 & 3.9 \\
$71 \%-80 \%$ & 3.9 & 3.3 & 2.3 \\
$81 \%-90 \%$ & 3.3 & 2.0 & 1.0 \\
$91 \%-99 \%$ & - & 0.7 & - \\
$100 \%$ & - & 3.3 & 1.0 \\
Total & 100.0 & $\mathbf{1 0 0 . 0}$ & $\mathbf{1 0 0 . 0}$ \\
\hline
\end{tabular}

\section{Analysis}

Where appropriate, each question was analysed by subject domain; formal statistical comparisons were made between subject groups (see Table 2 above), using the $\chi^{2}$ test. Analysis by institution type was also carried out using the $\chi^{2}$ test - these were grouped according to Table 1: pre-1992 universities, post-1992 universities and Higher Education Colleges. In each case, any statistically significant differences at the $5 \%$ or $1 \%$ level have been noted.

\section{Teaching}

Reading lists

Reading lists are provided by an unsurprising $85.9 \%$ of the respondents. Table 5 shows that the majority of those who replied provide reading lists 'in handouts' (65.8\%), followed by 'as a bibliography' (52.3\%). Handouts and bibliographies may have been available in electronic and/or print formats. Those teaching and/or researching in the Arts and Humanities were significantly more likely to use a bibliography; those in Science and Engineering were significantly less likely to do so $(p<0.01)$. A relatively high proportion noted using links in a website (45.1\%) and a wide range of other methods of provision were listed, such as using their institution's Virtual Learning Environment (VLE), module handbooks, via PowerPoint presentations, and verbally during discussions.

Table 5: Ways in which reading lists are provided to students

\begin{tabular}{lcc} 
& $\begin{array}{c}\text { No of } \\
\text { responses }\end{array}$ & $\%$ \\
\hline In handouts & 200 & 65.8 \\
As a bibliography & 159 & 52.3 \\
In a website as links & 137 & 45.1 \\
Other & 40 & 13.2 \\
\hline
\end{tabular}




\section{Types of scholarly output used in teaching}

In terms of materials used by academics in their teaching, Table 6 shows the wide variety of provision, with a strong emphasis on 'traditional' materials. The majority of participants indicated using print textbooks (81.5\%) in their teaching; slightly fewer specified the use of articles in refereed print (74.7\%) and electronic (73.6\%) journals. The statistical tests found various significant differences with regard to subject discipline:

- Those teaching in the Arts and Humanities were significantly more likely $(p<0.01)$ to use articles in refereed print journals in their teaching

- Those in Medical and related subjects were significantly more likely, and those in Science and Engineering were significantly less likely $(p<0.05)$ to make use of articles in refereed electronic journals

- $\quad$ Professional journals (print) were significantly more likely to be used by those teaching in Arts and Humanities and in Medical and related subjects $(p<0.01)$

- Professional journals (print) were significantly less likely to be used by those teaching in Science and Engineering $(p<0.01)$

- Articles in electronic professional journals were significantly less likely to be used by those teaching in Science and Engineering $(p<0.01)$

Around two thirds of respondents also indicated that they use chapters in printed books for their teaching; this was significantly more likely amongst the Arts and Humanities respondents $(p<0.01)$ and significantly less likely amongst those in Science and Engineering. The situation was exactly the same in the case of chapters in electronic books $(p<0.01)$. Table 6 shows that relatively few participants make use of the more novel technologies such as e-zines (10.2\%), wikis (9.4\%) and blogs (7.2\%). Slightly more popular, however, are subject repositories (18.1\%) and discussion lists (17.0\%).

With regard to institution type, the statistical tests showed that those in post-1992 universities were significantly more likely to use articles in printed professional journal articles and in electronic professional journals ( $p<0.01$ in each case). They were also significantly less likely to use research monographs $(p<0.01)$ and to make use of material from subject repositories $(p<0.05)$. Conversely, those from pre-1992 institutions were significantly less likely to use articles in professional electronic journals $(p<0.01)$ and significantly more likely to use chapters in electronic books $(p<0.05)$. 
Table 6: Formats included as part of teaching materials

\begin{tabular}{|c|c|c|}
\hline Format & $\begin{array}{l}\text { No of } \\
\text { responses }\end{array}$ & $\%$ \\
\hline Textbooks (print) & 216 & 81.5 \\
\hline Articles in refereed journals (print) & 198 & 74.7 \\
\hline Articles in refereed journals (electronic) & 195 & 73.6 \\
\hline Chapters in books (print) & 184 & 69.4 \\
\hline Articles in professional journals (electronic) & 124 & 46.8 \\
\hline Articles in professional journals (print) & 124 & 46.8 \\
\hline Conference papers & 103 & 38.9 \\
\hline Material on your institutional website & 101 & 38.1 \\
\hline Multimedia/audiovisual materials including film and television excerpts & 100 & 37.7 \\
\hline Textbooks (electronic) & 85 & 32.1 \\
\hline Chapters in books (electronic) & 84 & 31.7 \\
\hline Research monographs (print) & 78 & 29.4 \\
\hline Newspapers (print) & 71 & 26.8 \\
\hline Newspapers (electronic) & 63 & 23.8 \\
\hline Magazines (print) & 57 & 21.5 \\
\hline Material from institutional repositories & 55 & 20.8 \\
\hline Research monographs (electronic) & 51 & 19.2 \\
\hline Material from subject repositories & 48 & 18.1 \\
\hline Discussion lists & 45 & 17.0 \\
\hline Material on your personal website & 43 & 16.2 \\
\hline E-zines & 27 & 10.2 \\
\hline Wikis & 25 & 9.4 \\
\hline Other social software supporting group interaction & 20 & 7.5 \\
\hline Blogs & 19 & 7.2 \\
\hline Conference posters & 13 & 4.9 \\
\hline Other & 19 & 7.2 \\
\hline Total respondents & 265 & \\
\hline
\end{tabular}

Other formats which participants reported using as part of their teaching included PowerPoint slides, lecture notes, videos and DVDs, compact discs, music scores, image databases, websites, material from news websites, electronic workbooks and tutorials, video recordings of respondent's own lectures, on-line e-book of digitised materials and podcast (audio).

\section{Influences on the choice of teaching materials}

As to the influences on choice of content when providing materials for students, respondents were presented with a list of suggestions and asked to rate how often each one influenced their choice. The responses are summarised in Fig 1 below which presents a mixed picture. As can be seen, subject discipline is most often cited as having an effect on the choice of teaching material content - an overwhelming $77.6 \%$ of respondents chose 'often' in response to this. In addition, a total $64.8 \%$ of respondents thought that the availability of print materials in the library is at least sometimes an issue when providing materials for 
students. Only $17.4 \%$ and $11.5 \%$ respectively found their technical competence and the support available an influence when providing teaching materials. It was clear that relatively few of the participants were involved with distance learners $-37.8 \%$ thought the question was not applicable.

\section{Take in Figure 1}

\section{Value of various formats for teaching}

Having investigated the use of various formats, it was thought important to find out how valuable these were to respondents in their teaching. Fig 2 illustrates the responses to this question; once again printed textbooks were popular and were most often chosen as being 'very valuable' (60.5\%). Articles in refereed electronic journals were the next most often chosen in this context (53.9\%), followed by articles in refereed print journals (45.4\%). Datasets were 'very valuable' for only $10.5 \%$.

\section{Take in Figure 2}

There were a number of differences between respondents from the various types of institution. Respondents from pre-1992 institutions were significantly less likely to rate articles in professional journals, whether print or electronic, as 'very valuable' and significantly more likely to rate them as 'not valuable'. Those working in post-1992 universities were significantly less likely to find research monographs 'very valuable', and more likely to find electronic textbooks 'very valuable'. Respondents from HE colleges were least likely to find non-scholarly resources of no value.

\section{Take in Figure 3}

Fig 3 compares the responses from university based respondents concerning electronic journals - there were insufficient responses overall finding such material 'not valuable' to include HE colleges in the formal comparison. Respondents from post-1992 universities place significantly higher value on articles from e-journals than do those from pre-1992 universities $(p<0.01)$. There was no difference in the responses of these two groups concerning articles in print journals, or electronic research monographs.

\section{Creation of teaching material}

In an attempt to investigate the use of the new technologies in the creation of teaching material, participants were presented with a list and asked to indicate whether they ever produce teaching material using any of these tools. As can be seen from Table 7, none of the technologies is being used to a great extent by the survey respondents, apart from discussion lists and simulation software. 
Table 7: Creation of teaching material

\begin{tabular}{lcc} 
& $\begin{array}{c}\text { Number } \\
\text { using }\end{array}$ & $\%$ \\
\hline Discussion lists & 70 & 32.1 \\
Simulation software & 46 & 21.1 \\
Wikis & 30 & 13.8 \\
Blogs & 28 & 12.8 \\
YouTube & 23 & 10.6 \\
Computer games & 11 & 5.0 \\
Any other social software supporting group interaction & 10 & 4.6 \\
Total & $\mathbf{2 1 8}$ & $\mathbf{1 0 0 . 0}$ \\
\hline
\end{tabular}

A Virtual Learning Environment (VLE) software was available to $72.7 \%$ of participants, but only $58.6 \%$ had made use of it; $25.7 \%$ had not. Only $4.3 \%$ did not know whether such software was available to them; $11.5 \%$ did not reply. The potential of VLEs in teaching is very great both in terms of the amount of digital material that could be provided in a coordinated way and also, in theory, the level of institutional support that should be available for academics to create and make their material available. From the findings of this study, it seems as if it is still being used in a traditional way rather than at its most innovative.

Respondents were also asked whether they collaborate with others when providing teaching material - the examples of other academics and librarians were given. A total of $55.9 \%$ indicated that they do collaborate in this way, whilst $33.2 \%$ do not. Those working in Medical and related subjects were significantly more likely to collaborate $(p<0.01)$ and those in Science and Engineering were significantly less likely to do so $(p<0.01)$. Those who replied affirmatively were asked to provide further details.

Of those who offered more information, 53 noted that their collaboration was with the library, usually to ensure adequate resources are available or to provide links to the library catalogue within reading lists.

\section{Creating digital outputs}

Respondents were questioned on their use of software to create digital outputs in a teaching context, the availability of any support for such use and whether they have sufficient knowledge to achieve their targets when creating digital outputs. Table 8 shows that around half of all respondents have support within their department for using software to create digital outputs, although statistical tests showed that those working in HE Colleges were significantly less likely to have such support $(p<0.01)$. A similar proportion $-46.4 \%-$ have experience of using such software. A lower proportion - 31.6\% - feel that they have sufficient knowledge to achieve their aims when creating digital outputs.

Statistical tests showed that those teaching in Science and Engineering were significantly more likely to have experience of using software to create digital outputs and that those in Medical and related subjects were significantly less likely to do so $(p<0.01)$. Those in post1992 universities were significantly less likely to have experience of using this software $(p<0.05)$. In addition, those teaching in Science and Engineering were significantly more likely to feel they have sufficient knowledge when creating digital outputs $(p<0.01)$. 
Table 8: Creating digital outputs

\begin{tabular}{lccc}
$\begin{array}{c}\text { Yes } \\
(\%)\end{array}$ & $\begin{array}{c}\text { No } \\
(\%)\end{array}$ & $\begin{array}{c}\text { response } \\
(\%)\end{array}$ & $\begin{array}{c}\text { No } \\
\text { incl. }\end{array}$ \\
\hline 46.4 & 43.1 & 10.5 & 272 \\
51.0 & 33.9 & 15.1 & 258 \\
31.6 & 54.3 & 14.1 & 261 \\
\hline
\end{tabular}

Those who felt they had insufficient knowledge to achieve their aspirations when creating digital outputs were asked to comment on whether they thought this was because of a lack of the appropriate training. Of those who went on to answer this question, just over half $(51.7 \%)$ thought this was a result of a lack of the appropriate training; $25.6 \%$ felt it was not and $22.7 \%$ did not know.

\section{Comments relating to teaching issues}

When invited to make comments relating to teaching issues, respondents noted time as a barrier to their use of a wider variety of forms of scholarly output in teaching. This included a lack of time to attend training (where it is available), to prepare, to experiment with and to revise the support material for a module. This was particularly true in cases when participants worked part-time or were unsure of the technology. It was suggested that the task might need to be undertaken by others on behalf of individual academics. Another concern related to the importance placed on teaching as compared to research within individual institutions; this necessarily impacts on the time available.

Several respondents were just beginning to use the newer technologies; where there was growing support within individual departments, development was likely to be at an early stage. However, a lack of consistency in approach within departments was seen as a potential difficulty.

Some participants were concerned about the opinions and reactions of their students towards different kinds of scholarly output. Therefore, appropriateness and student response are factors in creating and using digital media. Students may prefer traditional methods to material such as electronic books and electronic means of delivering lectures. It was also suggested that students may be less adept at and/or disposed to using electronic resources than might be assumed. It was also noted that supplying material electronically may result in higher costs resting on students (for printing and so on) and that, having already extracted fees, institutions should bear more of these costs.

Some concerns were expressed relating to printed materials compared to those presented electronically. It was noted that the great majority of scholarly publishing is in print, and that as a result, perhaps academics should be concentrating their efforts into directing students towards printed material. It was also suggested that it is important to avoid becoming preoccupied with new technology at the same time as recognizing the value of a variety of formats. 


\section{Research}

\section{Sources of material for research}

When undertaking research, respondents mostly chose to make use of the more traditional sources of material. Table 9 shows the value placed by respondents on various kinds of scholarly output as sources of material for their research. As can be seen, articles in refereed electronic and printed journals were most often rated as 'very valuable'. The third most highly rated output was informal communication. Perhaps not surprising, given RAE concerns, is the fact that the least important output was non-scholarly resources. Statistical tests showed that respondents from pre-1992 universities were significantly more likely and those from post-1992 universities were significantly less likely $(p<0.05)$ to rate articles in printed professional journals as 'not at all valuable'. In addition, pre-1992 university researchers were significantly less likely $(p<0.01)$ to rate articles in professional electronic journals as 'very valuable'; those from post-1992 universities were significantly less likely to rate these as 'not at all valuable' $(p<0.01)$. These findings reflect those related to the scholarly output used in teaching. There were no statistically significant differences according to subject discipline.

Table 9: Value of outputs as sources of material for research

\begin{tabular}{lcccc} 
& $\begin{array}{c}\text { Very } \\
\text { valuable } \\
(\%)\end{array}$ & $\begin{array}{c}\text { Valuable } \\
(\%)\end{array}$ & $\begin{array}{c}\text { Not } \\
\text { valuable } \\
(\%)\end{array}$ & $\begin{array}{c}\text { No } \\
\text { incl. }\end{array}$ \\
\hline Articles in refereed journals (electronic) & 79.1 & 17.0 & 4.0 & 253 \\
Articles in refereed journals (print) & 76.7 & 21.3 & 1.9 & 258 \\
Informal communication such as talking to colleagues & 57.2 & 37.4 & 5.3 & 243 \\
Conference proceedings & 41.7 & 46.5 & 11.8 & 254 \\
Articles in professional journals (electronic) & 42.9 & 30.2 & 26.9 & 245 \\
Research monographs (print) & 42.3 & 35.3 & 22.4 & 241 \\
Databases & 41.1 & 29.9 & 29.0 & 241 \\
Textbooks (print) & 40.6 & 47.3 & 12.1 & 239 \\
Articles in professional journals (print) & 37.3 & 38.2 & 24.5 & 249 \\
Research monographs (electronic) & 30.8 & 36.3 & 32.9 & 234 \\
Textbooks (electronic) & 24.7 & 42.9 & 32.5 & 231 \\
Datasets & 20.4 & 29.6 & 50.0 & 226 \\
Non-scholarly resources, e.g. magazines, newspapers, & & & & 39.3 \\
$\quad$ popular websites, broadcast media & 16.7 & 43.9 & 239 \\
\hline
\end{tabular}

Table 9 shows that only $20.4 \%$ of respondents considered datasets to be 'very valuable' in their research (with 29.6\% rating them 'valuable' and 50.0\% rating them 'not valuable'). Since these were thought by the study team to be a recent and potentially very useful innovation for research, respondents were asked to give details of how often they made use of them. Nevertheless, datasets were not used particularly often by respondents, although electronic datasets were more popular than those in print. Just $2.3 \%$ of respondents use print datasets and $12.8 \%$ use electronic datasets 'often'; $50.3 \%$ of respondents 'never' use print datasets and $40.5 \%$ 'never' use electronic datasets. 


\section{Dissemination of output}

In terms of disseminating research output, the preferred outlets were similar to those which were favoured for source material (see Table 9). As can be seen from Table 10, articles in refereed print journals (53.1\%) and conference papers (47.8\%) are the most popular for 'often' disseminating; this is not surprising, given the emphasis placed on such outputs by the RAE. Indeed, the four top answers are those on which the majority of emphasis is placed for the RAE. It is also clear from Table 10 that respondents are moving towards a tendency to publish in electronic journals (third most popular for 'often' disseminating) rather than in the new technologies, such as electronic books, institutional and subject repositories, blogs and wikis. The less formal kinds of publication were not particularly popular - whether print (e.g. magazines) or electronic (e.g. e-zines).

Table 10: Dissemination of research output

\begin{tabular}{|c|c|c|c|c|c|}
\hline & $\begin{array}{l}\text { Often } \\
(\%)\end{array}$ & $\begin{array}{c}\text { Sometimes } \\
(\%)\end{array}$ & $\begin{array}{c}\text { Rarely } \\
(\%)\end{array}$ & $\begin{array}{c}\text { Never } \\
(\%)\end{array}$ & $\begin{array}{l}\text { No } \\
\text { incl. }\end{array}$ \\
\hline Articles in refereed journals (print) & 53.1 & 30.7 & 9.8 & 6.3 & 254 \\
\hline Conference papers & 47.8 & 36.9 & 9.4 & 5.9 & 255 \\
\hline Articles in refereed journals (electronic) & 36.7 & 26.5 & 12.4 & 24.3 & 226 \\
\hline Chapters in books (print) & 22.8 & 36.6 & 17.7 & 22.8 & 232 \\
\hline On your personal website & 18.3 & 13.6 & 11.3 & 56.8 & 213 \\
\hline Conference posters & 18.2 & 30.2 & 24.0 & 27.6 & 225 \\
\hline On your institutional website & 17.4 & 24.7 & 18.7 & 39.3 & 219 \\
\hline Articles in professional journals (print) & 14.4 & 27.1 & 24.9 & 33.6 & 229 \\
\hline Research monographs (print) & 13.0 & 22.2 & 17.6 & 47.2 & 216 \\
\hline Textbooks (print) & 11.2 & 24.6 & 17.0 & 47.3 & 224 \\
\hline Articles in professional journals (electronic) & 10.3 & 16.8 & 24.3 & 48.6 & 214 \\
\hline Chapters in books (electronic) & 9.0 & 14.8 & 12.4 & 63.8 & 210 \\
\hline Institutional repositories & 8.1 & 11.8 & 17.1 & 63.0 & 211 \\
\hline Subject repositories & 7.2 & 12.0 & 17.3 & 63.5 & 208 \\
\hline Other digital output forms such as blogs, wikis, etc & 5.5 & 6.0 & 10.4 & 78.1 & 201 \\
\hline Textbooks (electronic) & 5.3 & 9.6 & 14.8 & 70.3 & 209 \\
\hline Research monographs (electronic) & 5.2 & 11.3 & 15.1 & 68.4 & 212 \\
\hline Magazines (print) & 3.2 & 19.0 & 28.2 & 49.5 & 216 \\
\hline Broadcast media & 2.4 & 12.1 & 22.7 & 62.8 & 207 \\
\hline E-zines & 2.4 & 5.4 & 12.2 & 80.0 & 205 \\
\hline Newspapers (electronic) & 1.4 & 7.2 & 14.0 & 77.3 & 207 \\
\hline Newspapers (print) & 1.4 & 12.5 & 21.8 & 64.4 & 216 \\
\hline Other & 4.4 & 1.1 & 3.3 & 91.1 & 90 \\
\hline
\end{tabular}

Other places in which respondents noted disseminating their research included websites of other institutions, research websites, research seminars, workshops, press conferences, press releases, industry seminars and events, project documentation and DVDs. Those responding negatively or not all were mainly new researchers who had only just begun considering the dissemination of their research. 
Dissemination of research output in collaborative media

In order to find out the extent to which research is being disseminated via the new technologies, respondents were then asked to state how often they discuss their research in discussion lists, blogs, wikis and other collaborative software. As can be seen from Table 11 , very few participants were making use of these technologies. There were no statistically significant differences between subject and according to institution type.

Table 11: Discussion of research in collaborative software

\begin{tabular}{lccccc} 
& Often & Sometimes & Rarely & Never & No incl. \\
\hline Discussion lists & 3.5 & 12.0 & 18.6 & 65.9 & 258 \\
Blogs & 1.2 & 4.4 & 9.6 & 84.7 & 249 \\
Wikis & 0.8 & 3.3 & 10.2 & 85.7 & 245 \\
Other collaborative software & 0.6 & 1.7 & 1.7 & 96.1 & 178 \\
\hline
\end{tabular}

The only other collaborative software types noted were e-mail and discussion boards.

\section{Potential barriers to research}

When asked about potential barriers to research, it was clear that feelings were similar with regard to all of the four choices offered. The responses are summarised in Table 12, from which it can also be seen that none of the four options seemed 'often' to be a particular barrier.

Table 12: Potential barriers to research

\begin{tabular}{lccccc} 
& $\begin{array}{c}\text { Often } \\
(\%)\end{array}$ & $\begin{array}{c}\text { Sometimes } \\
(\%)\end{array}$ & $\begin{array}{c}\text { Rarely } \\
(\%)\end{array}$ & $\begin{array}{c}\text { Never } \\
(\%)\end{array}$ & $\begin{array}{r}\text { No } \\
\text { incl. }\end{array}$ \\
\hline $\begin{array}{l}\text { Lack of the appropriate technology to access } \\
\text { electronic articles }\end{array}$ & 8.9 & 17.5 & 36.6 & 37.0 & 257 \\
$\begin{array}{l}\text { Lack of the appropriate training in using } \\
\quad \text { available technology }\end{array}$ & 8.4 & 22.4 & 31.6 & 37.6 & 250 \\
$\begin{array}{l}\text { Lack of the appropriate technology to access } \\
\quad \text { electronic media, e.g. images }\end{array}$ & 6.3 & 20.3 & 36.3 & 37.1 & 256 \\
$\begin{array}{l}\text { Lack of the appropriate technology to access } \\
\quad \text { electronic books }\end{array}$ & 5.5 & 20.1 & 38.2 & 36.2 & 254 \\
Other & 31.6 & 7.9 & 7.9 & 52.6 & 76 \\
\hline
\end{tabular}

The two main issues cited as 'other' potential barriers were time and access to materials. Firstly, many respondents noted a lack of time - to do research, to engage with electronic sources, to explore further possibilities and for training. On the second issue, several respondents noted that their institution's library had not subscribed to all the journals they require, either in print or electronically. In the case of electronic journals and electronic books (although it was commented that few books are available electronically), it was therefore often the case that the technology was in place but the journal required was not available. This was attributed to a lack of funding within the institution; having no budget to buy articles was also a concern. It was noted in addition that institutional subscriptions to electronic versions of printed journals often do not extend back as far as the cessation of the printed form in the library, thereby leaving some editions unavailable. The bundling of journals which may yield some less relevant sources and omit other, more useful ones was also perceived to be a problem. 
Cost was an issue, for example, accessing relevant datasets can represent a significant cost as can the continual need to buy and upgrade relevant software. Cost was also cited in terms of lack of funds for travel and subsistence for training and a lack of capital resources.

Some computing issues were raised, the first being that there is always a learning curve with any new software, and the second being the lack of information about which software tools to use for a particular problem - both of these can act as a barrier.

\section{Comments relating to research issues}

In common with the comments relating to teaching issues, respondents noted that a key constraint on research is time. It was also clear that participants were often experiencing difficulties balancing their teaching load with research. However, it was suggested that electronic resources can make research more viable for many staff under pressure both to research and to teach. As a result, some respondents think it is a problem that they do not have electronic access to certain key journals; furthermore, ever wider availability of electronically archived journals and books is thought to be necessary. Conversely, some participants expressed a general preference for printed sources; this was due mainly to favouring print for reading, and a wish to read and touch original documents.

Interestingly, some detailed information was offered relating to theoretical physics research. This suggested that "journals (paper or electronic) published since the early 1990s have become irrelevant, except for accreditation for the RAE, promotional purposes and the like. The community works almost exclusively from the electronic archive, arXiv.org. We are quite willing to act as our own referees, if necessary, although it is the journal articles (if published) that will be cited in references. It is for that reason alone that journals still have a use". This presents a singular case of scholarly output coming to rely increasingly on an electronic method of presentation.

\section{Intellectual Property Rights (IPR) issues}

\section{Clearing copyright for teaching purposes}

IPR issues are often confusing for those who encounter them; this is a common problem for both researchers and teachers, who are creating and making use of original material. In the context of the survey, respondents were asked whether they believed they can reproduce any third party materials for teaching purposes without having to clear copyright. The great majority of the participants (88.5\%) replied negatively, and only 9.9\% replied 'yes'. Those who replied with 'No' were asked to indicate how often in practice they check for themselves whether permission is necessary to reproduce materials for teaching purposes. As can be seen from Fig 4, the highest proportion of respondents do this 'sometimes' (33\%), although as many as $23 \%$ replied 'not usually'.

\section{Take in Figure 4}

There is evidence that problems are encountered when attempting to clear rights, so respondents were asked to indicate which of a list they had experienced. The most often encountered problem was 'difficulty tracking down the copyright owner' (32.2\%), followed by 'no response to request' (22.4\%). Just $6.9 \%$ had received a 'negative response' and 5.9\% selected 'other', which included nine respondents commenting on the prohibitive costs of reproducing copyright material, and three indicating that if they think that there might be a copyright problem, they tend to avoid the material. It was also apparent that there was a 
need for clear information to be available internally and respondents experienced a lack of time and support when clearing rights.

\section{Datasets}

Participants were asked whether they thought there were any IPR issues relating to datasets of which they and their students should be aware. The highest proportion of respondents did not know (43.4\%); a further 37.2\% indicated that the question was not applicable to them. Just $7.2 \%$ replied 'no' and $6.3 \%$ replied 'yes' with the remainder failing to give a response.

Those who did reply 'yes' were asked to give details. The comments received were as follows:

- $\quad$ For example, we have a strict licence for use of digital OS maps that we have to bring to the attention of our students. There are many similar examples

- YouTube, iTunes, burning CDs etc

- I always try to side step these issues by using materials which are out of copyright or has been published by colleagues who I can ask for permission

- Knowing when and how much to reproduce for study purposes from each source, care in quoting accurately with full credit to sources.

- $\quad$ All materials are potentially protected by IPR and copyright

- We always contact originator before use

- $\quad$ Lack of clear statements on copyright

- $\quad$ Full permission given for datasets utilised

- Check conditions on "further" use , e.g. HESA

- $\quad$ Can't pass to 3rd parties. Need to acknowledge sources of data in publications

- I have used ESRC data archives, and the conditions for use, both for academics and students is clearly set out; also use data from CHILDES, which is free to use as long as you cite the sources shown in the manual on publication

- $\quad$ PGs need to know if and when they can reproduce images at specified resolutions

- $\quad$ Are they sufficiently anonymised to preclude IPR issues

- Only educational use/acknowledge source

\section{Combinations of materials}

The last issue relating to IPR was concerned with the ownership of combinations of materials from a variety of sources which have been brought together in a single package. Participants were asked to indicate who they believed owns the IPR in such materials; the highest proportion (44.4\%) thought that it is 'the creators or their institutions', while $39.8 \%$ of the respondents did not know - this is worrying as it is possible that these respondents are contravening copyright legislation on occasion. Two percent thought they owned the IPR in 
this situation. In fact, the creator of a combination of materials enjoys copyright in that combination as well as the copyright being owned by the creators of each component piece - they all jointly own the copyright in the final work.

It is interesting to compare these results with those of a recent study of attitudes about the rights and rewards for author contributions to repositories for teaching and learning (Bates et al., 2007). The authors asked respondents about the policy of their institution on who owns the copyright in teaching materials at their institution, and found that over half (54.9\%) of them were unsure about the issue. Believing that their institution owns the copyright were $26 \%$, whilst $12.8 \%$ thought that the academic who creates the material is the holder of the copyright.

\section{Comments relating to IPR issues}

The general comments relating to IPR issues in connection with scholarly output unsurprisingly showed varying degrees of knowledge on this subject. As two participants noted, this is a potential "minefield", and many researchers seem unaware of the implications. Indeed, one respondent commented, "my relative ignorance of these issues speaks for itself!" Others were more fortunate in having knowledgeable staff able to provide advice on IPR issues, or even to clear all necessary rights on their behalf.

\section{Discussion}

The results of the survey indicate that despite their high profile, Web 2.0 and social software are not yet prevalent in the teaching and research of this group of academics. The reasons given for not embracing innovative technologies were the familiar ones of lack of time, training and support. Given the pioneering activities reported in the literature one might describe the current picture as one with enthusiastic adopters on the edge of the circle with a more conservative core who need to be further encouraged and supported. The age group of the participants may also be a factor in these results.

The respondents were highly positive towards the now well established presence of electronic journals as resources for teaching and research. Responses showed that a large proportion use material from refereed print (74.7\%) and electronic journals (73.6\%) in their teaching.

Reading lists (85.9\%) and course materials (79.9\%) are the typical resource provided for teaching. Although printed formats remain the most popular for this purpose, the use of internet sites is widespread amongst the participants in the survey.

The results of the study also confirmed that few respondents were using non-scholarly output (e.g. newspapers and magazines) and even fewer were making use of the newer technologies in their teaching. These findings are mirrored by the responses relating to the value of formats for teaching; the most valued formats were printed textbooks, being cited as 'very valuable' by $60.5 \%$ of respondents. The second most valued format was articles in refereed electronic journals (53.9\% 'very valuable') and articles in refereed printed journals (45.4\%). Here, however, it was clear that electronic sources were more likely to be considered 'very valuable'; this is likely to be due to the convenience of access to electronic sources which was the subject of various comments relating to the questionnaire. 
All of the questions which included issues relating to VLEs showed that Blackboard was the most frequently available software, at least with the participants in this particular survey. Blackboard was mentioned as being social software, supporting group interaction, a format included as part of teaching and for the creation of teaching material. It was also the most widely available software; accessible to 138 respondents (45.4\% of the total respondents). Although some comments were positive about Blackboard, others noted contrary opinions, suggesting that the software has various limitations or had not been implemented in a particularly flexible way within individual institutions. However, any novel software would be likely to provoke such mixed feelings, and it could be that those with negative opinions would feel the same about any VLE software.

It is noteworthy that, when asked about influences over the choice of content for teaching materials, the majority (77.6\%) indicated that this was 'often' subject discipline. The lack of availability of print materials in the library was also relatively 'often' a barrier (64.8\%); this is obviously an issue since it was also seen as one of the main potential barriers to research. The more technical aspects of this issue, however, were less of a problem and relatively few participants involved in teaching thought that technical competence and support were 'often' an influence. Furthermore, since $72.7 \%$ of the respondents have institutional access to VLE software, this was not a problem either.

The survey showed that just over half of the respondents regularly collaborate when creating teaching material; those who did were mainly teaching in a team. Since social software facilitates collaboration, it is likely that it will be able to aid these participants in future, although it is not being used in this way at present.

Some respondents identified students as a potential barrier to using some electronic resources, in the sense that some students either find it difficult, or are unwilling, to use such new technology. This is counter to expectations, as research findings demonstrate that students have embraced new technologies in their personal life and are happy to do so in their studies (JISC, 2007b). Evidence to support this finding is sparse and to date, mainly anecdotal. The response may conceal a defence mechanism on the part of some of the academics surveyed, who are reluctant to change and therefore invoke a perceived similar reluctance in some students. A JISC study (CIBER, 2008) reported that, although enthusiastic in the use of new technology, students' information literacy skills were not well developed and there was also some reluctance on their part to use social software sites, which they regarded as their own space, for their university studies (Ipsos MORI, 2007). A key finding from this (MORI) study was the feeling from students that "if all learning is mediated through technology, this will diminish the value of the learning" (Ipsos MORI, 2007).

Cohen (2008) agrees that some academics have problems with Web 2.0, finding it a distraction, a disruption, disturbing and even dumb (Cohen, 2008 p.472). Writing from a librarian's perspective she supports a programme of positive advocacy. A recent feature in the Times Higher Education (Fearn, 2008) also reports concerns that academics are finding it hard to keep up with 'transliterate' students and corroborates the finding of this study that although there are some 'champions' of the technologies, many academics are unsure or anxious. 
When the dissemination of research and sources of material were considered, it was clear that these are linked to the RAE. Those publications considered of most value for the RAE are articles in refereed journals, conference papers and chapters in edited books. These were the most popular outlets in which to disseminate research, and were valued most highly as sources of material for research. It is likely that there is a mutual interdependence at work here - if a form of scholarly output is necessary for the RAE, the highest quality research is likely to find its way into this format and therefore be often used as a source of material for research.

A very important finding of the survey was that lack of time was an issue for both teachers and researchers. This involved problems with balancing time spent on teaching with that on research, as well as having time to familiarise themselves with the novel technologies. In teaching this included a lack of time to attend training (where it is available) and time to prepare, experiment with and revise the support material for a module. One of the main issues cited as a potential barrier was a lack of time - to do research, to engage with electronic sources, to explore further possibilities and for training. This is obviously an issue which may have an effect on the uptake of new technologies.

Contrary to expectations, datasets (both printed and electronic) are not being used particularly often by those researchers responding to this survey. It is noteworthy, however, that electronic datasets are more popular than those in print. This is perhaps not surprising, particularly in the case of larger datasets which are easier to manipulate and keep up to date in an electronic format. The lack of awareness of datasets in general is likely to be due to either a scarcity of such sources, or a lack of knowledge of their existence, a state of affairs that is currently being addressed at institutional level (University of Oxford 2008) and beyond - this is an issue which would lend itself to further research in future.

\section{Conclusions and recommendations for further research}

Changing technologies pose challenges for everyone in HE. The needs of learners, teachers and researchers are evolving fast, even if, according to the findings of this study, the evolution is not occurring at a consistent rate. The survey has identified some aspects of the transition from print to digital as patchy for these respondents and has singled out various issues for further research. Subject discipline is clearly an issue, and the example of those working in theoretical physics research relying almost exclusively on a single electronic archive (arXiv.org) is key here. Further research into particular disciplines could be carried out to investigate in more detail whether there are further examples of this kind.

The views and practices of students were not considered in this research, though a possible issue was identified by some respondents - is there any reluctance on the part of learners to embrace new media? If true, this would act as an important barrier to the use of such outputs; academics are unlikely to wish to use formats which are unacceptable to those whom they are teaching. Current and future studies need to clarify this issue.

The survey shows that the RAE has an obvious effect on trends in scholarly output, particularly in the case of research activity. However, there are plans to modify considerably the RAE after this (2008) implementation and research will be needed to investigate the impact of its successor. 
Lastly, it appears from this study that respondents are generally confused about the IPR issues relating to all kinds of scholarly output formats. It therefore seems that further research investigating this issue, particularly with regard to the newer technologies could be beneficial.

In conclusion, it can be seen that the picture relating to the use of scholarly output in research and teaching is largely a mixed one. There is much innovative research and development underway by those who are most directly involved, that is, e-learning developers, educational technologists and librarians. And although a number of academics are undoubtedly actively involved, the wider population in HE cannot, as yet, be regarded as 'champions' of all aspects of changing scholarly communication.

\section{References}

Alexander, B. (2006), "Web 2.0: A new wave of innovation for teaching and learning?", EDUCAUSE Review, Vol. 41 No. 2, pp. 32-44.

Allen, B. (2007), "Developing the best blend? From blended e-learning to blended learning", Update, Vol. 6 No. 3, pp. 26-28.

Anderson, P. (2007), What is web 2.0? Ideas, technologies and implications for education, JISC Technology \& Standards Watch, available at:

www.jisc.ac.uk/media/documents/techwatch/tsw0701b.pdf (accessed 05 September 2008).

Armstrong, J. and Norton, B. (2006), Use of research content in undergraduate teaching, unpublished report commissioned by the JISC Scholarly Communications Group.

Bates, M., Loddington, S., Manuel, S. and Oppenheim, C. (2007), "Attitudes to the rights and rewards for author contributions to repositories for teaching and learning", $A L T-J$, Research in Learning Technology, Vol. 15 No. 1, pp. 67-82.

Brabazon, T. (2007), The university of Google, Ashgate, Aldershot.

Brynko, B. (2008), "Research 2.0: the age of collaboration", Information Today, Vo. 25 No.8 Sept, p.34.

CIBER (2008), Information behaviour of the researcher of the future, CIBER Briefing Paper, available at:

www.ucl.ac.uk/slais/research/ciber/downloads/ggexecutive.pdf (accessed 24 September 2008)

Codone, S. (2004), "Reducing the distance: A study of course websites as a means to create a total learning space in traditional courses", IEEE Transactions on Professional Communication, Vol. 47 No. 3, pp. 190-199.

Cohen, S. F. (2008), "Taking 2.0 to the faculty: why, who and how", College \& Research Libraries News, September, pp.427-475.

Fearn, H. (2008), "Grappling with the digital divide", Times Higher Education, 14 August, pp. 37-39. 
Fraser, M. (2005), "Virtual research environments: overview and activity" Ariadne, Vol. 44, available at: www.ariadne.ac.uk/issue44/fraser/ (accessed 20 August 2009).

Glogoff, S. (2006) The LTC Wiki - experiences with integrating a wiki in instruction, available at: www.wikiineducation.com/display/ikiw/The+LTC+Wiki++Experiences+with+Integrating+a+Wiki+in+Instruction (accessed 05 September 2008).

HESA (2007) Resources of Higher Education Institutions 2006/07, HESA, Cheltenham, Glos.

Housewright, R. and Schonfeld, R. Ithaka's 2006 Studies of Key Stakeholders in the Digital Transformation of Higher Education New York: Ithaka, 18 August 2008, available at: ithaka.org/publications/facultyandlibrariansurveys (accessed 24 September 2008).

Ipsos MORI (2007). Student expectation study (for JISC), available at: http://www.jisc.ac.uk/publications/publications/studentexpectations (accessed 14 November 2008)

JISC (2007a). Web 2.0 and social software: an introduction, JISC Briefing paper, available at:

www.jisc.ac.uk/publications/publications/web2socialsoftwarev1.aspx (Accessed 24 September 2008).

JISC (2007b) In their own words: understanding the issues and benefits of social software, available at:

www.jisc.ac.uk/media/documents/programmes/elearningpedagogy/iowpersonalsoftwarepdf. pdf (accessed 24 September 2008)

Kirkwood, A. and Price, L. (2007) "Learners and learning in the twenty-first century: what do we know about students' attitudes towards and experiences of information and communication technologies that will help us design courses?" Studies in Higher Education, Vol. 30 No. 3, pp. 257-274.

LASSIE. (2008) Social software, libraries and distance learners: final literature review. University of London. Centre for Distance Education, available at: clt.Ise.ac.uk/Projects/LASSIE_lit_review_final.pdf (accessed 24 September 2008).

Marcum, D. and George, G. (2003) "Who uses what? Report on a National survey of information users in colleges and universities", D-Lib Magazine, Vol. 9 No. 10, available at: www.dlib.org/dlib/october03/george/10george.html (accessed 05 September 2008).

Myhill, M., Shoebridge, M. and Snook, L. (2009), "Virtual research environments - a web 2.0 cookbook?" Library Hi Tech, Vol. 27 No. 2, pp.228-238.

Nikam, K. and Rajenda, B. H. (2009), "Moving from script to science 2.0 for scholarly communication", Webology, Vol. 6 No. 1, available at:

http://www.webology.ir/2009/v6n1/a68.html (accessed 18 August 2009).

Owen, M., Grant, L., Sayers, S. and Facer, K. (2006) Social software and learning, Bristol: Futurelab, available at: www.futurelab.org.uk/research/opening_education.htm (accessed 05 September 2008). 
Phoebe Pedagogic Planner (2007), available at: phoebe-app.conted.ox.ac.uk/ (accessed 05 September 2008).

Placing, K., Ward, M., Peat, M. and Teixeira, P. (2005) "Blogging in science and science education", in Placing, K. (Ed.), UniServe Science Blended Learning Symposium Proceedings, available at: science.uniserve.edu.au/pubs/procs/wshop10/ (accessed 05 September 2008).

Proctor, R. et al. (2009), "impact od web 2.0 on scholarly communication" [slides]. Workshop on scientific writing and new patterns of scientific communication, $5^{\text {th }}$ International Conference on e-Social Science, Cologne, 24 June 2009. Available at: http://www.slideshare.net/MeikPoschen/impact-of-web-20-on-scholarly-communication (accessed 18 August 2009).

Robinson, L. (2007), "Impact of digital information resources in the toxicology literature", Aslib Proceedings, Vol.59 No.4/5, pp.342-351.

Robson, D. (2008), "Personalising physics publishing with web 2.0." Research Information, No. 18-20, Oct-Nov, pp.18-20.

Selwyn, N. (2009), "The digital native: myth and reality", Aslib Proceedings, Vol. 61 No. 4, pp. 364-379.

Sharpe, R., Benfield, G., Roberts, G. and Francis, R. (2006) The undergraduate experience of blended e-learning: a review of UK literature and practice, London, Higher Education Academy, available at:

www.health.heacademy.ac.uk/themes/elearning/hsltblendedlearning.doc (accessed 05 September 2008).

Shirky, C. (2003), "Ontology is overrated: Categories, links and tags", available at: www.shirky.com/writings/ontology_overrated.html (accessed 05 September 2008).

Simmons, B. (2008), "Learning (2.0) to be a social library", Tennessee Libraries, Vol. 58 No. 2, available at: http://www.tnla.org/associations/5700/files/582simmons.pdf (accessed 18 August 2009).

Skipper, M. (2006), "Would Mendel have been a blogger?" Nature Reviews Genetics, No. 7, p. 664.

Smith, D. (2008), "A parallel universe? Blogs, wikis, web 2.0 and a complicated future for scholarly communication", Serials, Vol.21 No. 1, pp.14-18

Swan, A. (2006), "Overview of scholarly communication", in Jacobs, N. (Ed.), Open access: Key strategic, technical and economic aspects, London, Chandos, pp. 5-14.

University of Oxford. Office of the Director of IT. (2008) Scoping digital repository services for research data management, available at: www.ict.ox.ac.uk/odit/projects/digitalrepository/docs/ScopingStudyInterviewsWorkshop\%20Findings.pdf (accessed 24 September 2008). 
Wakeham, M. and Garfield, D. (2005), "Supporting both learning and research in a UK post1992 university library: A case study", Journal of Librarianship and Information Science, Vol. 37 No. 4, pp. 175-186. 